\title{
Distribution and length composition of lemon sharks (Negaprion brevirostris) in a nursery ground in southern Cuba
}

\author{
Alexei Ruiz-Abierno • J. Fernando Márquez-Farías $(1)$ Robert E. Hueter • Lázaro \\ Macías-Romero • J. Manuel Barros-García • Lisandra García-Córdova • Andrés \\ Hurtado • Valerie Miller
}

Received: 29 June 2020 / Accepted: 12 November 2020 / Published online: 19 November 2020

(C) The Author(s) 2020

\begin{abstract}
Characterization of essential habitat for sharks is a key requirement for effective conservation of shark populations. In Cuba, shark essential habitat is largely undocumented. Here we present the first study of a shark nursery area in Cuban waters, for the lemon shark. Nursery areas for
\end{abstract}

A. Ruiz-Abierno · L. Macías-Romero

Centro de Investigaciones Marinas, Universidad de La Habana, 16

\# 114, CP 11300 Playa, La Habana, Cuba

J. F. Márquez-Farías $(\bowtie)$

Facultad de Ciencias del Mar, Universidad Autónoma de Sinaloa, Paseo Claussen S/N. Los Pinos, CP 82000 Mazatlán, Sinaloa, Mexico

e-mail: fmarquez@uas.edu.mx

R. E. Hueter

Center for Shark Research, Mote Marine Laboratory, 1600 Ken

Thompson Parkway, Sarasota, FL 34236, USA

J. M. Barros-García

Empresa para la Conservación de la Ciénaga de Zapata

(ECOCIENZAP), C. Zapata, Cuba

L. García-Córdova

Centro Interdisciplinario de Ciencias Marinas del Instituto

Politécnico Nacional, Av. IPN S/n, Col. Playa Palo de Santa Rita,

23096 La Paz, Baja California Sur, Mexico

A. Hurtado

Centro de Reproducción de la Ictiofauna Indígena, Playa Larga, C.

Zapata, Cuba

V. Miller

Environmental Defense Fund, 301 Congress Ave., Suite 1300,

Austin, TX 78701, USA lemon sharks are typically surrounded by mangroves and contain sandy substrate where the young can feed, grow, move, and eventually disperse from the area. We conducted our study in Cuba's La Salina Wildlife Refuge during 20152019 , to understand the role this refuge might play as a lemon shark nursery area, by documenting the distribution and length structure of juveniles. Our results indicate that juvenile lemon sharks are present throughout much of the refuge with no clear pattern of aggregation by size. The size range of all juveniles captured was 39.8$108.0 \mathrm{~cm}$ precaudal length (PCL) with a mode in length-class $70.0-75.0 \mathrm{~cm}$ PCL. The mean size and weight of all individuals during the study period was $75.8 \mathrm{~cm}$ PCL and $5.5 \mathrm{~kg}$, respectively. We infrequently observed neonates in May, June, and September with size range 39.8-55.5 cm PCL. Enforcement of management regulations, difficult access to the refuge for fishers and other user groups, and isolation from human settlements are factors that help maintain nearly pristine conditions in La Salina Wildlife Refuge. The size/age structure of lemon sharks likely represents a population unaltered by human influence. We recommend our study be expanded to contribute to shark conservation and management as outlined in Cuba's National Plan of Action for sharks.

Keywords Nursery area Cuba Carcharhinid . National Park 


\section{Introduction}

Coastal sharks use geographically discrete areas where pregnant females give birth to their pups (Castro 1993). Bass (1978) classified shark nurseries into "primary nurseries," where pregnant females carrying full term embryos, neonates, and young-of-the-year (YOY) are found, and "secondary nurseries," where juveniles older than one year occur. Heupel et al. (2007) defined three criteria for an area to be identified as a shark nursery: (1) juvenile sharks are more commonly encountered in the area than other areas; (2) juvenile sharks have a tendency to remain in or return to the area for extended periods; and (3) the area or habitat is repeatedly used by juvenile sharks across years. Many species of tropical sharks use semi-enclosed bodies of shallow water such as bays and estuaries with different habitat types (coral reefs, mangrove forests, seagrass meadows, salt marshes, mud and sand flats). Mangrove environments and seagrass meadows are preferred habitat for some carcharhinid sharks (White et al. 2004) while other coastal shark species are adapted to use open systems such as bays, river deltas, shallow beaches, and other coastal fringe habitats (Branstetter 1990; Castro 1993).

Knowledge about characteristics of shark nursery areas is mostly based on coastal species due to their occurrence in bays, estuaries, river deltas, and shallow coastal waters. In warm temperate to tropical regions, these habitat types are often highly productive, semienclosed systems, typically surrounded by mangroves, sandbars or reefs (Castro 1993). The time young sharks spend in nurseries depends on both biotic and abiotic factors. Sharks abandon nurseries as larger juveniles, often mixing with adults in deeper waters (Branstetter 1990). Despite the fact that fishermen have realized the importance of specific essential fish habitat (EFH) for centuries, scientific recognition of the importance of habitat use of sharks by dates back only to the early 1990 s, leading to a growing understanding of the roles of EFH for conservation of shark populations (Simpfendorfer and Heupel 2004). With this awareness has come enthusiasm to protect those marine areas that provide EFH for critical life stages of depleted shark populations.

The lemon shark (Negaprion brevirostris) was first described by the eminent Cuban ichthyologist Felipe Poey more than 150 years ago as a species found in Cuban waters (Poey 1868). It is a large coastal shark with tropical distribution in the Atlantic Ocean,
Caribbean and Eastern Pacific. This species prefers warm and shallow water habitats with sandy substrate surrounded by mangroves (Morrissey and Gruber 1993a, b). Much of what is known about lemon shark reproduction and nursery areas has resulted from longterm studies in the Bahamas over the past four decades (Kessel et al. 2016). The species is a viviparous carcharhinid that uses coastal habitats to give birth and provide food and protection from predators for the young. As with most coastal sharks, lemon shark reproduction is seasonally synchronized with variation in geographic regions. In the northwestern Atlantic, births occur between April and July, and in the southwestern Atlantic, births occur between January and April. Lemon sharks are born at $39-49 \mathrm{~cm}$ precaudal length (PCL) after a prolonged gestation of close to one year (Gruber and Stout 1983: Brown and Gruber 1988, Freitas et al. 2006).

On the southwestern coast of Cuba, the La Salina Wildlife Refuge is situated in the southern portion of the Zapata Swamp National Park, just west of the Bay of Pigs (Fig. 1). It is a desirable destination for recreational fly fishing year-round. The main targets in this fishery are bonefish (Albula spp.), tarpon (Megalops atlanticus), permit (Trachinotus falcatus) and common snook (Centropomus undecimalis). La Salina refuge is overseen by the Empresa para la Conservación de la Ciénaga de Zapata (Zapata Swamp Conservation Enterprise), which operates a field station there. Based on casual observations by station technicians of small sharks in the refuge, we conducted an exploratory survey to confirm the species and document the size and distribution of these sharks. To understand the La Salina estuarine area's ecological aspects and its use as juvenile habitat for the lemon shark, we sought to determine the distribution and length structure of juveniles in the refuge. The study was responsive to research needs specified in the National Plan of Action (NPOA) for sharks in Cuba (PAN-Tiburones 2015), with a goal of informing both fisheries management and conservation initiatives for sharks in Cuban waters.

\section{Materials and methods}

Study area

La Salina is a $186 \mathrm{~km}^{2}$ estuary with characteristics typical of a tropical estuarine system (Nagelkerken 


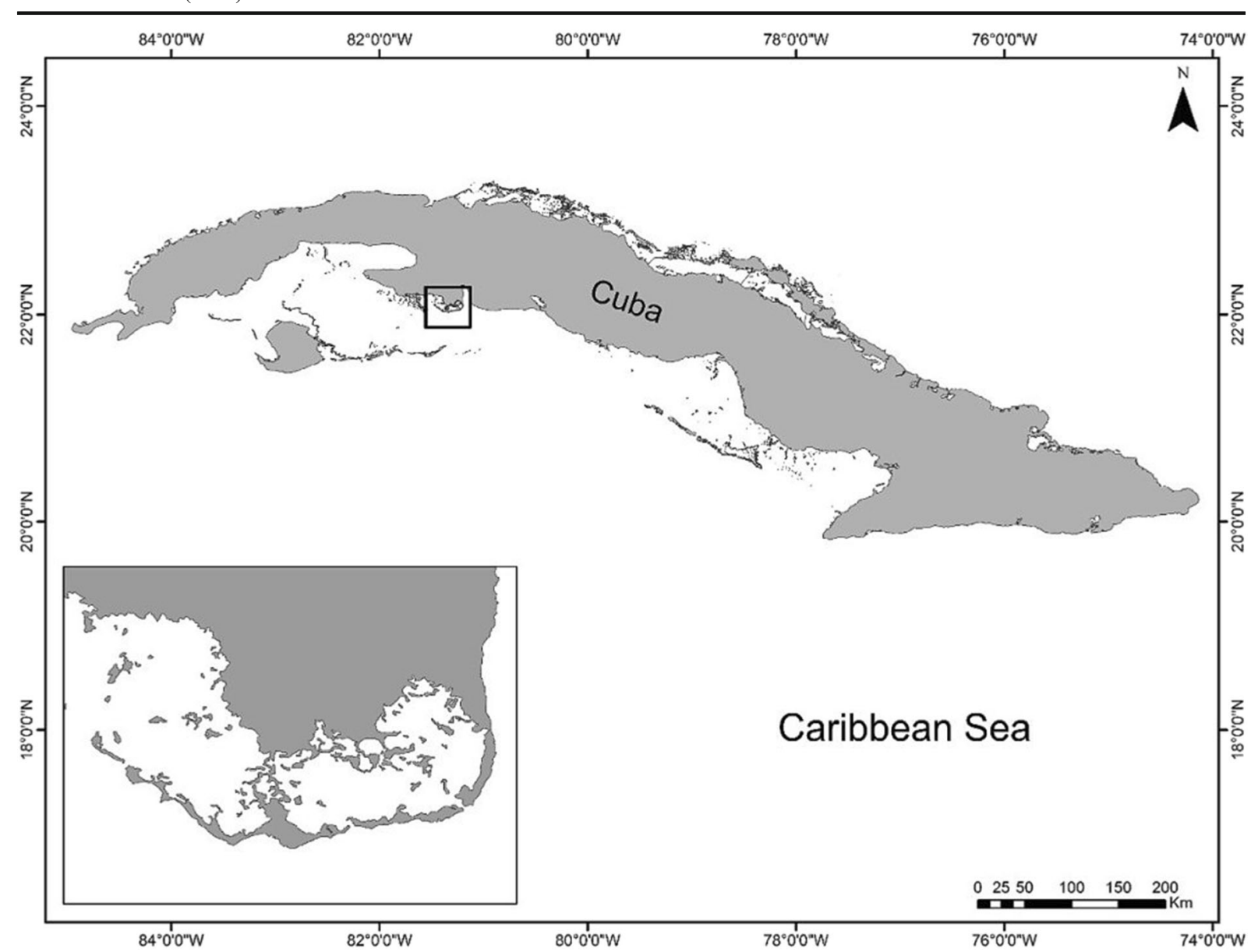

Fig. 1 La Salina study area (red rectangle and inset) on the southwestern Cuban coast

et al. 2008; Martínez-Daranas and Suárez 2018) and with at least five openings into the Gulf of Cazones and the Caribbean Sea (Fig. 1). The variety of bottom habitat types in the estuary includes extensive sandbars, open mangrove areas, rocky-bottom lagoons, and sandy, muddy, and mixed bottoms (Ault 2008). Small areas close to mangrove keys and shallows commonly contain low algae coverage, dominated by genera Acetabularia, Laurencia, Codium and Penicillus, and coverage by manatee grass Syringodium filiforme. In the deepest areas close to openings on the southern border, the bottom is dominated by turtle grass Thalassia testudinum. Small keys with red mangroves (Rhizophora mangle) comprise most of La Salina's southern border, with small, shallow lagoons. In this area, tidal amplitude is low ( $25 \mathrm{~cm}$ max.), such that the average depth of $49 \mathrm{~cm}$ in these small lagoons makes them difficult to access, except for deeper channels on the south side with average depth of $2.2 \mathrm{~m}$. Fishing inside the refuge is prohibited, except for the catchand-release recreational fly fishing, and other human activity in the area is practically nonexistent.

\section{Surveys}

Surveys were conducted in La Salina during the period of September 2015 to May 2019, using a 7 m outboard fishing vessel towing a $3 \mathrm{~m}$ fiberglass boat. Different hook-and-line methods were used to catch sharks, including bottom longlines (LL), drumlines (DL), and rod and reel (RR). Bait consisted of species found in the area, mainly mojarra (Gerres cinereus), gray snapper (Lutjanus griseus), grunts (Haemulon spp.), and great barracuda (Spyraena barracuda). The longline consisted of a $2 \mathrm{~mm}$ diameter monofilament mainline of $380 \mathrm{~m}$ length anchored on both ends, with gangions attached every $7 \mathrm{~m}$. In total 50 gangions of $2 \mathrm{~m}$ length were used. Each gangion of $5 \mathrm{~mm}$ diameter 
monofilament had a baited 10/0 circle hook (no wire was used) and was attached to the mainline with a tuna clip. Soak time varied from one to three hours with periodic review of the gear to minimize mortality of the sharks. If we observed a shark caught on the gear before haulback time, we retrieved the shark immediately and rebaited the line. The drumlines consisted of a concrete block to which a single baited $10 / 0$ circle hook on a $4 \mathrm{~m}$ monofilament line (200 pound-test) and a buoyed line were attached. Rod and reel were used opportunistically to catch lemon sharks when freeswimming animals were seen close to the boat. Drumlines were haphazardly set in the study area, while bottom longlines were set along the borders of large flats and across channels and deep openings. The positions of sets were recorded by Garmin GPS 72H (start/end points for longline sets, single locations for drumlines and rod and reel) and mapped to visualize sampling effort and catch as well as capture and recapture positions.

\section{Data collection and tagging}

All live captured sharks were measured, sexed, weighed, tagged, and released. Length measurements included PCL, fork length (FL), total length (TL), and stretch total length (STL). Neonates were identified by the presence of an open umbilical scar; juveniles with closed umbilical scars included post-neonatal young-ofthe-year (YOY) and larger juveniles. Each individual was weighed with an electronic scale (LOADCELLOCS-03-L) and plastic net/stretcher. Live sharks smaller than $100 \mathrm{~cm}$ TL were tagged before release with a nylon-head dart tag; individuals larger than $100 \mathrm{~cm}$ TL were tagged using a stainless steel-head dart tag (both tags Hallprint Pty Ltd., South Australia). The tags were inserted just below the first dorsal fin across the body midline. Larger animals were also double-tagged with a plastic Rototag in the first dorsal fin (Hueter et al. 2007). Animals that did not survive capture were retained for the teaching collection at the University of Havana's Center for Marine Research (CIM-UH).

\section{Length analysis}

Biometrics of lengths ( $\mathrm{PCL}=a+b \mathrm{TL} ; \mathrm{TL}=a+b \mathrm{PCL})$ and length-weight $\left(\mathrm{W}=a \mathrm{TL}^{b}\right)$ were analyzed by linear regression. Coefficients of the length-weight relationship were obtained by least-squares regression to the $\log$-transformed data $(\log \mathrm{W}=\log a+b(\log \mathrm{TL})$. The value of $a$ was re-converted back with its antilogarithm $\left(10^{a}\right)$. Logistical issues made regular monthly surveys in all years impossible; therefore, lengths by month were tabulated combining all years to analyze monthly length-frequency distributions of individuals inhabiting the refuge. Length and weight frequency histograms were constructed to know the structure of the individuals in the refuge during the study period. The sex ratio was tested against a 1:1 expectation using a Chi-square test.

\section{Results}

Catch and distribution

During the 3.7 yrs. of the study we set 3012 hooks over 35 field days, consisting of a total of 271 sets comprising 57 longline, 202 drumline, and 12 rod and reel sets (Fig. 2). All sets were made during daylight hours except for two night sets. Two species of sharks were caught, lemon sharks (101) and nurse sharks Ginglymostoma cirratum (5). Teleost bycatch included great barracuda Sphyraena barracuda, Cubera snapper Lutjanus cyanopterus, and mutton snapper Lutjanus analis.

The five nurse sharks were found only in deeper waters $(>200 \mathrm{~cm})$ close to the openings that connect the La Salina system to the deeper water of the Gulf of Cazones. On the other hand, lemon sharks were captured mostly in the shallow waters of the coastal lagoons and the margins of mangrove keys ( $<60 \mathrm{~cm}$ depth), without showing evident patterns of size or sex distribution. We captured only one lemon shark longer than one meter $(108 \mathrm{~cm}$ PCL, $130 \mathrm{~cm} \mathrm{TL})$, in the southeast part of the area close to an opening to the Gulf. The capture of this individual was consistent with local fishing guide information that bigger sharks are spotted in the deepest areas close to the entrances or channels on the southern border.

\section{Biometrics}

The overall sex ratio of lemon sharks did not vary significantly from the 1:1 expected ratio (41 females, 60 males, $\left.X^{2}=3.574, P=0.059\right)$. Results of a linear regression for $\mathrm{PCL}=a+b(\mathrm{TL})$ was $a=2.25$ (CI:$0.05-4.55), b=0.786$ (CI:0.76-0.81) $\left(r^{2}=0.975\right.$, 


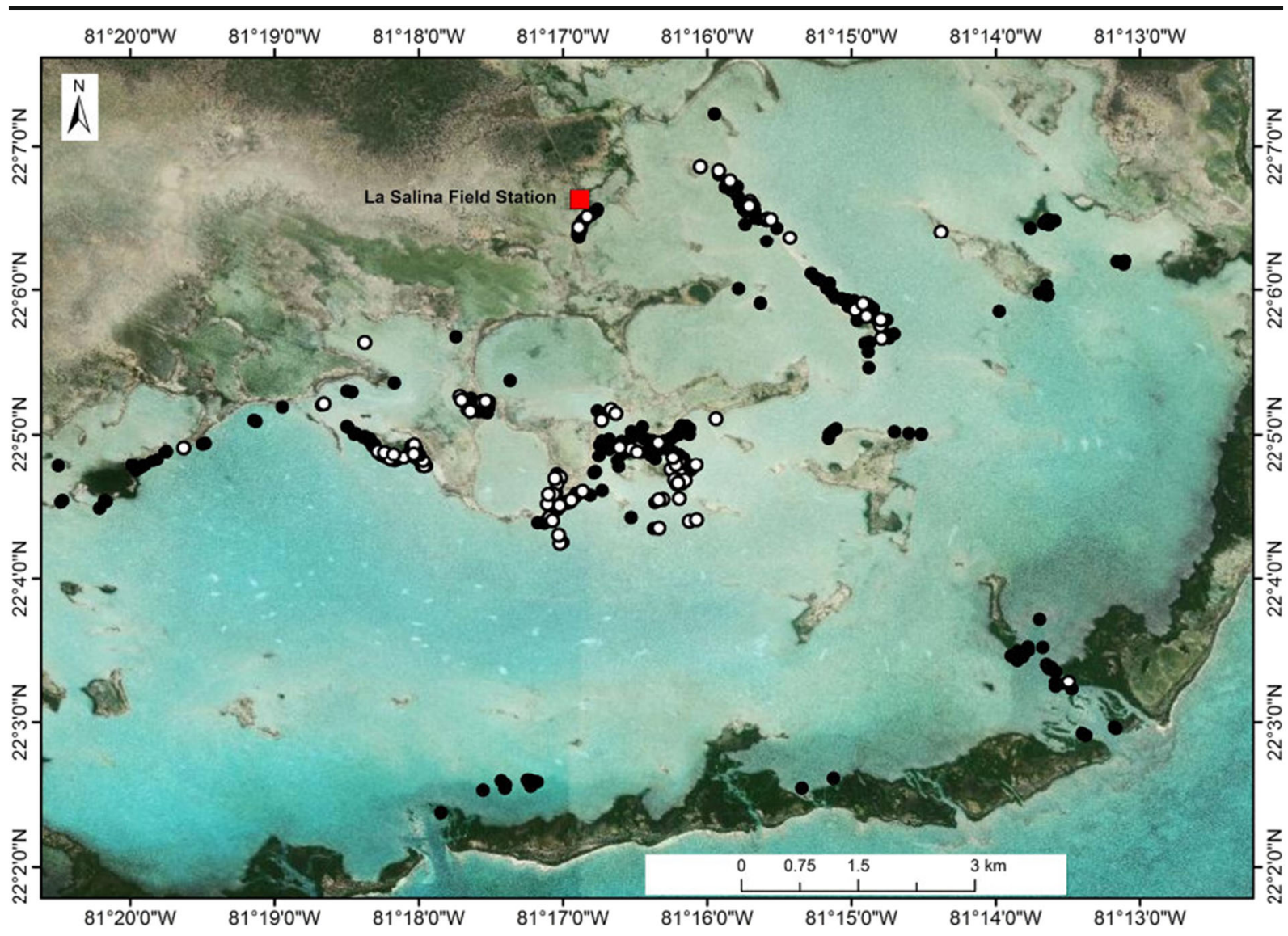

Fig. 2 Positions of sets for the survey for the entire study period $(\bullet)$. Sets with capture of at least one lemon shark (०). Red square shows the location of La Salina ecological field station

$P<0.0001, n=100)$ and for TL $=a+b(\mathrm{PCL})$ was $a=$ -0.55 (CI:-3.49-2.39), $b=1.239$ (CI:1.20-1.28) $\left(r^{2}=\right.$ $0.975, P<0.0001, \mathrm{n}=100)$. Sex was not a significant factor among the smallest measured sharks $(P=0.715)$. Length-weight relationship coefficients were $a=$ 0.000102 (CI: $0.000048-0.000218$ ), $b=2.496$ (CI: $2.3162-2.676)\left(r^{2}=0.94, P<0.001, n=49\right)$.

Length and weight structure

Despite the logistical challenges of conducting field work in La Salina, all months but January, August and October were represented in the samples (Table 1). The overall length-frequency distribution of the total data was bimodal, with modes ranging 70-75 cm PCL and $85-90 \mathrm{~cm}$ PCL. The mean size and weight of all individuals of lemon shark taken in La Salina during the study period was $75.8 \mathrm{~cm}$ PCL (39.8-108 cm PCL, s.d. $=14.13 \mathrm{~cm}, n=101)$ and $5.5 \mathrm{~kg}(1.1-9.8 \mathrm{~kg}$, s.d. $=2.27$, $n=50$ ), respectively (Fig. 3). For neonates, mean length and weight was $49.8 \mathrm{~cm}$ PCL (39.8-55.5 cm PCL, s.d. = $6.17, n=8)$ and $1.5 \mathrm{~kg}(1.1-1.9 \mathrm{~kg}$, s.d. $=0.267, n=7)$, respectively. Mean length and weight of non-neonate individuals was $77.3 \mathrm{~cm} \mathrm{PCL}$ ranging 41.5$108.0 \mathrm{~cm}$ PCL (s.d. $=12.98 \mathrm{~cm}, n=93$ ) and $5.6 \mathrm{~kg}(1.4-9.8 \mathrm{~kg}$, s.d. $=2.172 \mathrm{~kg}, n=43)$, respectively. Length and weight structure of lemon sharks in La Salina is presented in Fig. 3.

\section{Growth rate}

During the period of the study, three recaptures were obtained. The time at liberty, growth and growth rate of these three tagged individuals were: 482 days, $25.5 \mathrm{~cm}$ (62.0 to $87.5 \mathrm{~cm}$ PCL) and $19.31 \mathrm{~cm}$ year $^{-1} ; 112$ days, $5.5 \mathrm{~cm}$ (67.0 to $72.5 \mathrm{~cm} \mathrm{PCL})$ and $17.9 \mathrm{~cm} \mathrm{year}^{-1}$; and 111 days, $5.8 \mathrm{~cm}(67.5-73.3 \mathrm{~cm} \mathrm{PCL})$ and $19.1 \mathrm{~cm} \mathrm{year}^{-1}$. An additional recapture was reported by a fisherman outside La Salina, but the information provided on the recapture location and shark length was 
Table 1 Length-frequency distribution of captured lemon sharks (Negaprion brevirostris) by month. The number of neonates in a given month are shown in parentheses. No sampling effort during January, August and October

\begin{tabular}{|c|c|c|c|c|c|c|c|c|c|c|c|c|c|c|c|}
\hline \multirow{2}{*}{$\frac{\mathrm{PCL}}{(\mathrm{cm})}$} & & & \multirow[b]{2}{*}{ Jan } & \multirow[b]{2}{*}{ Feb } & \multirow[b]{2}{*}{ Mar } & \multirow[b]{2}{*}{ Apr } & \multirow[b]{2}{*}{ May } & \multirow[b]{2}{*}{ Jun } & \multirow[b]{2}{*}{ Jul } & \multirow[b]{2}{*}{ Aug } & \multirow[b]{2}{*}{ Sep } & \multirow[b]{2}{*}{ Oct } & \multicolumn{2}{|c|}{ Month } & \multirow[b]{2}{*}{ Total } \\
\hline & & & & & & & & & & & & & Nov & Dec & \\
\hline 35 & - & 40 & & & & & $1(1)$ & & & & & & & & 1 \\
\hline 40 & - & 45 & & & & & $4(2)$ & & & & & & & & 4 \\
\hline 45 & - & 50 & & & & & & & 1 & & & & & & 1 \\
\hline 50 & - & 55 & & & & & & (3) & 1 & & & & & & 4 \\
\hline 55 & - & 60 & & & & & & (1) & & & $2(1)$ & & & 1 & 4 \\
\hline 60 & - & 65 & & 2 & 2 & & 1 & & & & 2 & & & 3 & 10 \\
\hline 65 & - & 70 & & 3 & 4 & 1 & 1 & 3 & & & & & 1 & 1 & 14 \\
\hline 70 & - & 75 & & 1 & 4 & 5 & 3 & 8 & 1 & & & & & & 22 \\
\hline 75 & - & 80 & & & 3 & 2 & 2 & 3 & 1 & & & & & 2 & 13 \\
\hline 80 & - & 85 & & & & 1 & & & 1 & & & & 1 & 3 & 6 \\
\hline 85 & - & 90 & & 2 & & 4 & 1 & 2 & & & 1 & & 1 & 1 & 12 \\
\hline 90 & - & 95 & & 1 & & & & 1 & & & & & 1 & & 3 \\
\hline 95 & - & 100 & & & & & & 1 & & & & & & 2 & 3 \\
\hline 100 & - & 105 & & & & & & 1 & & & & & & & 1 \\
\hline 105 & - & 110 & & & & & & 1 & 1 & & & & & 1 & 3 \\
\hline Total & & & & 9 & 13 & 13 & 13 & 24 & 6 & & 5 & & 4 & 14 & 101 \\
\hline
\end{tabular}

unreliable. Information on the tagging and recaptures is summarized in Table 2. When comparing the lengths of the entire sample of the study period (2015-2019) with the sizes of the individuals when they were tagged and recaptured, variations in total growth can be seen (Fig. 4). That is, the shark that was tagged in December 2015 and recaptured in April 2017 grew 25 cm (Fig. 4, label $\mathrm{A} \rightarrow \mathrm{B}$ ), whereas the two sharks tagged in March 2018 and recaptured in June of the same year (Fig. 4 label $\mathrm{C} \rightarrow \mathrm{D}$ ) grew just over $5 \mathrm{~cm}$ (Table 2).

\section{Discussion}

Knowledge on shark nursery areas has affirmed their critical role in providing protection from predators and as feeding habitats for early life stages (Heupel and Hueter 2002; McCandless et al. 2007). The habitat for juvenile lemon sharks in La Salina is consistent with the conventional description of this species' nursery areas, which include shallow and semi-enclosed marine/ estuarine systems that have been extensively documented mainly in the Bahamas (Gruber et al. 1988; Morrissey and Gruber 1993a, b) and areas of the Southwest Atlantic (Tavares et al. 2016).
In our study, surveys were made in different parts of La Salina and we found no clear evidence that large individuals remain close to channels connecting to outside the estuary (Fig. 2). Based on the shape of the right side of the length-distribution, lemon sharks $>75 \mathrm{~cm}$ PCL appear to move in and out of the estuary. Hueter et al. (2007) observed that blacktip sharks (Carcharhinus limbatus) of Yalahau Lagoon, Mexico were found in swirls of turbid water in the central and western open parts of the lagoon. Heupel and Hueter $(2001,2002)$ found that blacktip sharks born in spring in Terra Ceia Bay, FL are concentrated near the bay's closed end, enlarging their perimeter of the system by the summer. In contrast, Duncan and Holland (2006) did not find a clear pattern of scalloped hammerhead (Sphyrna lewini) distribution in a Hawaii nursery area. They found young hammerheads tend to return to core areas after patrolling extensive zones with no clear pattern of habitat use during their early growth. The aggregation, distribution and habitat use of sharks in their nurseries apparently depend on species' lifestyle and growth rate, which ultimately is related to the ability of individuals to feed before leaving the nursery area. 

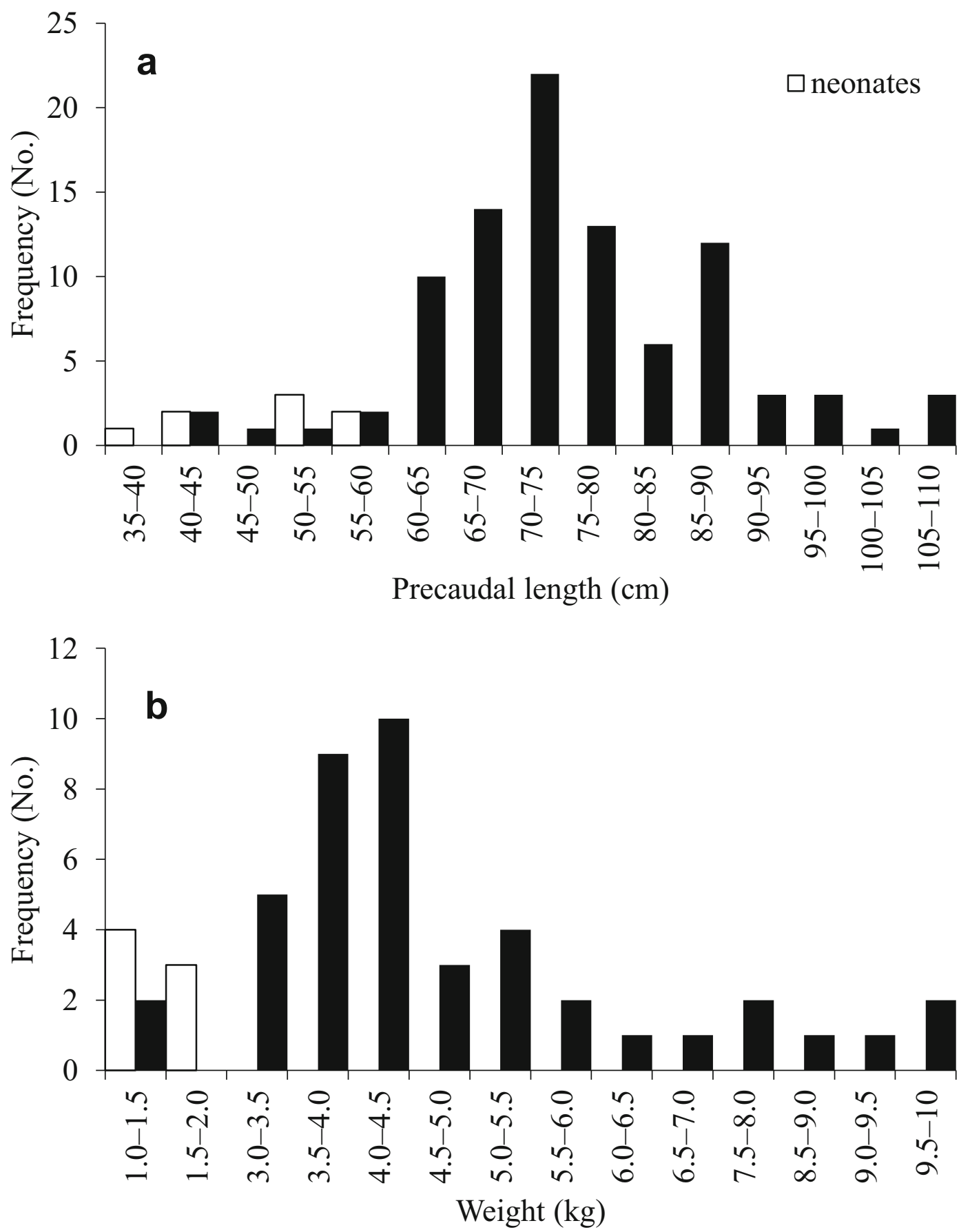

Fig. 3 Length (a) and weight (b) frequency distribution of lemon sharks (Negaprion brevirostris) captured and released in La Salina during the study period. Neonates are shown in white bars

Length frequency

Although at any given time there was a mixture of cohorts of several years in the La Salina nursery area, the size distribution showed a prominent mode in length class $70-75 \mathrm{~cm}$ PCL and weight interval $4.0-4.5 \mathrm{~kg}$ (Fig. 3). Tavares et al. (2016) reported a right-skewed length-frequency distribution for the lemon shark in Los Roques Archipelago National Park, Venezuela with a mode in length class $52.2-56.2 \mathrm{~cm}$ PCL. Comparisons 


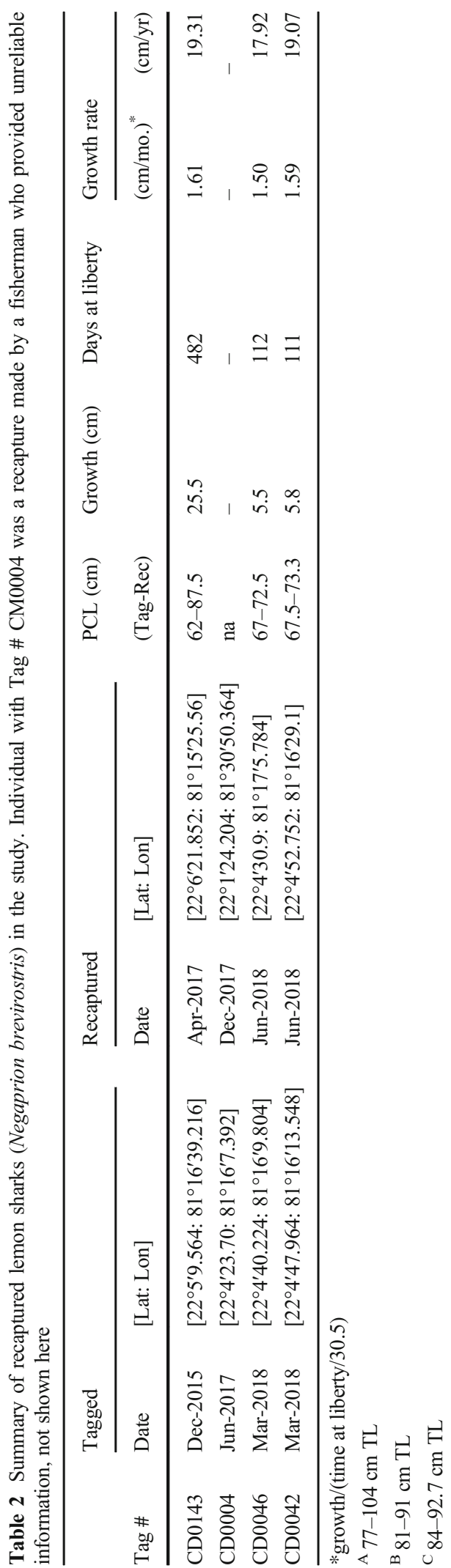

of our study with other areas is complicated by several factors. For instance, in the case of Los Roques, current or past fishing pressure adjacent to the nurseries with size-selective mortality by fishing gear could influence the shape of the size distribution in that location. Due to the lack of human interaction and no fishing mortality in our study area, we hypothesize that the length distribution observed in La Salina is unbiased and probably represents the natural size structure of individual juvenile lemon sharks in the nursery. Neonates in the present study were uncommon, possibly because these small sharks were seen to remain around mangrove roots and were unavailable to our fishing gear. Size of neonate lemon sharks from our study ranged $39.8-55.5 \mathrm{~cm}$ PCL $(n=8)$, which overlaps with the size ranges 41.55 $49.41 \mathrm{~cm}$ PCL (50-60 cm TL) reported for the Bahamas (Gruber and Stout 1983), 50.2-53.34 cm PCL (61$65 \mathrm{~cm} \mathrm{TL}$ ) for Florida Bay and Biscayne Bay in US waters (Castro 1993), and 44.14-52.91 cm PCL (54.9-65.9 cm TL) for Los Roques National Park, Venezuela (Tavares et al. 2016).

Based on previous studies of lemon sharks in the Bahamas (Brown and Gruber 1988), it was possible to incorporate information for modeling growth (i.e. average birth month, size at birth) at La Salina. Although the four recaptures were not sufficient to be conclusive on growth, it is useful information to visualize the growth pattern in La Salina and compare estimated lengths with studies in other areas (Brown and Gruber 1988). We adopted a procedure to estimate mean birth length and the growth coefficient $\left(L_{o}=47.9 \mathrm{~cm}\right.$ PCL and $k=$ $0.042^{-1}$ ), keeping fixed the value of $L_{\infty}=318 \mathrm{~cm}$ PCL taken from the literature, allowing us to determine the preliminary growth rate of young lemon sharks in La Salina.

Growth parameters reported for lemon sharks in the Bahamas by Brown and Gruber (1988) are $\left(t_{o}=-2.302\right.$, cm PCL, $k=0.057^{-1}, L_{\infty}=318 \mathrm{~cm}$ PCL were $L_{o}=39.1$ ) with an average growth rate per year of $14.22 \mathrm{~cm}$. Although the estimated average growth rate was slightly lower for La Salina $(10.47 \mathrm{~cm} / \mathrm{yr})$ than for the Bahamas $(14.22 \mathrm{~cm})$, average increments of predicted lengths from age- 0 to age- 4 were similar at $69.4 \mathrm{~cm}(88.7-44.5 \mathrm{~cm})$ and $68.3 \mathrm{~cm}(96-39.1 \mathrm{~cm})$, respectively. Another growth rate for the lemon shark was estimated by Morrissey and Gruber (1993a), who reported a mean PCL growth rate of $6.7 \mathrm{~cm}$ year $^{-1}$ from seven juvenile lemon sharks at Bimini, fitted with internal telemetry transmitters. Juveniles with Passive Integrated Transponder (PIT) tags in 


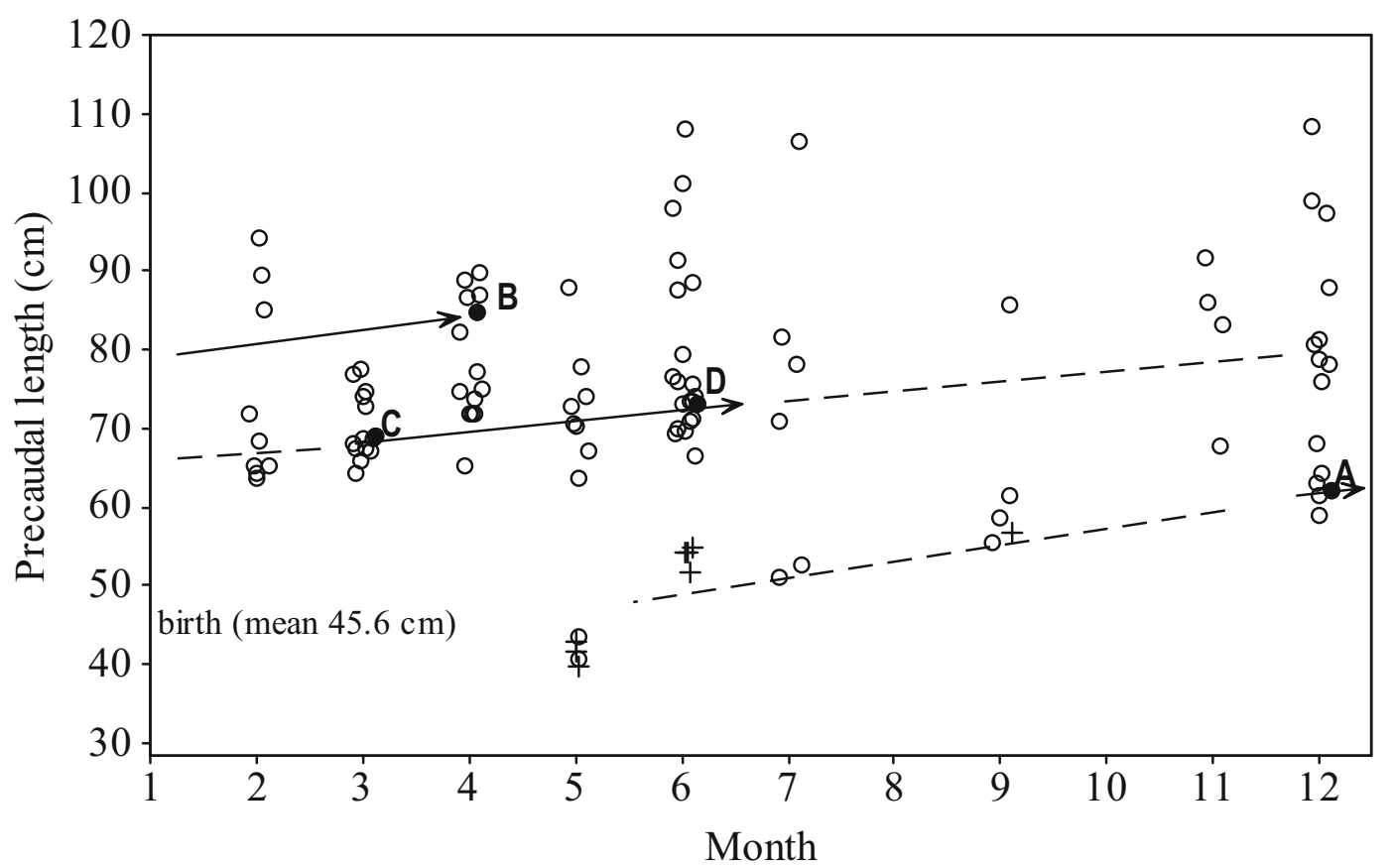

Fig. 4 Individual monthly lengths of young (०) and neonate (+) lemon sharks (Negaprion brevirostris) documented during the study period (2015-2018) in La Salina $(n=101)$. Overlapped are lengths of tagged/recaptured individuals $(\bullet)$ suggesting a consistent pattern of growth. Arrows (solid line) represent the connection of actual individuals tagged and recaptured. The individual tagged $(62 \mathrm{~cm}$ PCL) in December 2015 (A) was recaptured $(87.5 \mathrm{~cm}$

that same location have shown PCL growth rates of $6.0 \mathrm{~cm}$ year $^{-1}$ (Barker et al. 2005). At Marquesas Keys in Florida; however, the mean \pm S.D. growth rate for juvenile lemon sharks, also tagged with PITs, was $17.1 \pm 4.3 \mathrm{~cm} \mathrm{year}^{-1}$ in PCL (Manire and Gruber 1991), closer to the rate of $19.5 \pm 2.7 \mathrm{~cm}$ year $^{-1}$ obtained in the Atol das Rocas Biological Reserve, Brazil. Barker et al. (2005) also reported relatively high growth rates ( $\sim 20.0 \mathrm{~cm}$ TL/year) for juveniles of this species in Marquesas Keys, FL, although the sample size in that study was very small. In contrast, Henningsen and Gruber (1985) and Barker et al. (2005) reported lower values of early growth rates, for instance, around $8.0 \mathrm{~cm}$ $\mathrm{TL} / \mathrm{year}$ for the lemon shark in Bimini.

Our study was based on an extremely small sample size, so more research is needed on juvenile lemon shark growth in La Salina. Some studies suggest that differences in young shark growth rates are strongly related to human influence, causing degradation of the mangrove and seagrass ecosystems and pollution of the seawater (Tavares et al. 2016). These threats, together with differences in temperature, abundance, quality and
PCL) on April 2017 (B). Average of two individuals tagged (67 and $67.5 \mathrm{~cm}$ PCL) on March 2018 (C) were recaptured (72.5 and $73.3 \mathrm{~cm}$ PCL) on June 2018 (D). Dashed line is in relative position and presumably represents the general pattern of growth of lemon sharks in the nursery ground in La Salina. (Data of tagged and recaptured from Table 2). January $=1$

availability of prey, and level of competition and predation, may negatively affect the growth of juvenile sharks, as well as their survival and recruitment (Barker et al. 2005; DiBattista et al. 2011). Particularly for the inshore lemon shark, lunar phases and tidal influences may play an important role in food availability, affecting growth rates (Brown and Gruber 1988). In addition, it has been reported that the use of conventional external tags might reduce the growth of neonate and juvenile lemon sharks by $10-50 \%$, when compared with animals tagged with PIT tags (Freitas et al. 2006).

Protected areas for sharks in Cuba

Marine protected areas (MPAs) are a widely used tool for preservation of biodiversity, for restoration of deteriorated areas and fisheries (Kelleher 1999; Roberts and Hawkins 2000; Salm et al. 2000), and more recently, as a strategy for protecting threatened and endangered shark and ray populations (Davidson and Dulvy 2017; Mackeracher et al. 2019). MPAs for sharks may range from small coastal areas to vast MPAs that cover both 
coastal and pelagic zones (Davidson 2012; Dulvy 2013). Although the establishment of shark sanctuaries worldwide has increased since 2015, and $29 \%$ of the total protected ocean area has been designated exclusively for shark conservation, there is still great uncertainty about which shark and ray species can benefit from large-scale space protections (Davidson and Dulvy 2017; Mackeracher et al. 2019). In 2013, Cuba declared 84 protected natural areas, many of which included marine territory (CNAP 2013). Of these areas, nine belong to the National Park category. This category of protected area is the second strictest in Cuba and corresponds to IUCN Category II. Zapata Swamp is a National Park that includes La Salina Wildlife Refuge, and was also designated as a Biosphere Reserve in 2000 (IUCN Category VI) and Ramsar Site (2001). The swamp comprises a total of more than $4000 \mathrm{~km}^{2}$ and is the largest, best-preserved wetland in the Caribbean.

Some studies have found that smaller-scale MPAs have benefited certain inshore shark species. For instance, Espinoza et al. (2014) found that the relative abundance of sharks was significantly higher in non-fished sites of the Great Barrier Reef Marine Park, highlighting the conservation value and benefits of the potentially no-fishing areas as tools of MPAs. Caribbean reef sharks (Carcharhinus perezi), which exhibit high site fidelity at Glover's Reef Marine Reserve, Belize (Bond et al. 2012), had a stable population within this area for more than a decade, which suggests that marine reserves can be an effective conservation tool for reef-associated shark species (Bond et al. 2017). Despite this, mobility and the migratory nature of some shark species may limit the utility of MPAs, but the potential effectiveness of spatial protection may be enhanced in various ways (Acuña-Marrero et al. 2017). For example, although most MPAs do not cover a shark species' entire home range, benefits may still arise if core habitat use areas, especially those that support key life stages or functions (e.g., breeding, feeding, and gestation), are protected (Hooker et al. 2011). Current studies suggest that MPAs are likely to be site- and species-specific, with species that are reef-attached or philopatric to certain areas benefiting most from zones prohibited to fishing, even for some species that are highly migratory (Feldheim et al. 2002; Acuña-Marrero et al. 2017).

The topography, phenology and oceanographic characteristics of La Salina Wildlife Refuge provide essential habitats for many species of crustaceans, fishes, birds, and mammals, as well as the critically endangered Cuban crocodile, Crocodylus rhombifer (Ruiz-
Plasencia 2017). Although Cuba does not have a specific MPA for elasmobranchs, the Cuban NPOA-Sharks began the process of recognizing and studying critical habitats for sharks in Cuban waters. Our data demonstrate that La Salina serves as a primary nursery for lemon sharks according to accepted definitions of shark nursery areas (Branstetter 1990; Castro 1993; Heupel et al. 2007). With strong enforcement of refuge regulations, difficult access (being surrounded by a swamp), and isolation from human population centers, the lemon sharks of La Salina represent early life stages that likely are unaltered by significant human impacts.

It has been recognized and is intuitive that the identification and protection of nursery areas is a key element in the conservation of shark population and management of sustainable shark fisheries (Heupel et al. 2007). Despite this, shark populations also depend on other factors, such as life history traits, demography, food abundance, predation risk, and physical features of the environment, to thrive (Heithaus 2007; Cortés 2002, 2007). Our study is the first published research to focus on a shark nursery area in Cuba. It is our hope that this work will lead to further research on other nursery areas in Cuban waters, thereby contributing to nationwide efforts to conserve sharks and manage shark fisheries, as outlined in Cuba's NPOA-Sharks.

Acknowledgments We dedicate this work to the memory of Dr. Samuel H. Gruber, who inspired this research and supported the idea of conducting studies on lemon shark nursery areas in Cuba. We thank the Centro de Investigaciones Marinas de la Universidad de la Habana (CIM-UH), with special gratitude to CIM students and technicians (JM Febles Díaz, Pedro Reyes, Ariadna Rojas and Milena Trápaga), the Office of the Zapata Swamp National Park (ECOCIENZAP), and the Enridan fly fishing operator and the technicians and fly fishing guides at the La Salina Biological Station in the Zapata Swamp for their valuable logistical support during expeditions for the capture, tagging and release of specimens. Special gratitude is extended to MINAL and CICA for facilitation of all permits for this research. This study is part of the Tasks and Actions outlined in the NPOA-Sharks Cuba. We express our gratitude to the Environmental Defense Fund (EDF) for advising and supporting this study. Participation of JF Márquez-Farías was under a MOU between Universidad Autónoma de Sinaloa and EDF, and RE Hueter was supported by Mote Marine Laboratory. Daniel Carrillo Colin and Jesús Osuna are thanked for assisting in map preparation.

Authors' contributions ARA lead the data collection, designed and developed the manuscript structure, wrote the introduction, methods and results and discussion. JFMF participated in the data collection, methods and results and discussion. REH participated in manuscript structure, language edits and participated in many discussions. LMR participated in all data collection. JMBG 
participated in logistics and data collection. LGC participated in field work and data collection. AH participated in logistics and data collection. VM participated in language edits and discussion.

Funding This work was partially funded by Centro de Investigaciones Marinas.

Data availability Requests should be addressed to the Senior author.

\section{Compliance with ethical standards}

Conflicts of interest/competing interest The authors declare that they have no conflicts of interest.

Ethics approval Reviewed and approved in the permits.

Consent to participate Not applicable.

Code availability Not applicable.

Consent for publication The authors consent to publication of the manuscript, which has not been previously published in any journal.

Open Access This article is licensed under a Creative Commons Attribution 4.0 International License, which permits use, sharing, adaptation, distribution and reproduction in any medium or format, as long as you give appropriate credit to the original author(s) and the source, provide a link to the Creative Commons licence, and indicate if changes were made. The images or other third party material in this article are included in the article's Creative Commons licence, unless indicated otherwise in a credit line to the material. If material is not included in the article's Creative Commons licence and your intended use is not permitted by statutory regulation or exceeds the permitted use, you will need to obtain permission directly from the copyright holder. To view a copy of this licence, visit http://creativecommons.org/licenses/by/4.0/.

\section{References}

Acuña-Marrero D, Smith A, Hammerschlag N, Hearn A et al (2017) Residency and movement patterns of an apex predatory shark (Galeocerdo cuvier) at the Galapagos marine reserve. PLoS One 12:e0183669. https://doi.org/10.1371 /journal.pone. 0183669

Ault JS (2008) Biology and management of the world tarpon and bonefish fisheries. CRC series in marine biology. Taylor and Francis Group, Boca Raton, FL, 441 pp

Barker MJ, Gruber SH, Newman SP, Schluessel V (2005) Spatial and ontogenetic variation in growth of nursery-bound juvenile lemon sharks, Negaprion brevirostris: a comparison of two age-assessing techniques. Environmental Biology of
Fish 72:343-355. https://doi.org/10.1007/s10641-004-25843

Bass AJ (1978) Problems in studies of sharks in the Southwest Indian Ocean. Pp 545-594. In: Hodgson E. S., Mathewson R. F. (Eds.). Sensory biology of sharks, skates and rays. U.S. Department of the Navy, Office of Naval Research. Department of Navy, Arlington, VA, $666 \mathrm{p}$

Bond M, Babcock E, Pikitch E, Abercrombie D et al (2012) Reef sharks exhibit site-Fidelity and higher relative abundance in marine reserves on the Mesoamerican barrier reef. PLoS One 7(3):e32983. https://doi.org/10.1371/journal.pone.0032983

Bond M, Valentin-Albanese J, Babcock EA, Abercrombie D, Lamb NF, Miranda A, Pikitch EK, Chapman DD (2017) Abundance and size structure of a reef shark population is maintained within a marine reserve for more than a decade. Mar Ecol Prog Ser 576:1-10. https://doi.org/10.3354 /meps 12241

Branstetter S (1990) Early life history implications of selected carcharhinoid and lamnoid sharks of the Northwest Atlantic. Pp. 17-28. In: Pratt HL, Gruber S, Taniuchi T (eds) Elasmobranchs as living resources: advances in the biology, ecology, systematics, and the status of the fisheries NOAA Technical Report NMFS

Brown CA, Gruber SH (1988) Age assessment of the lemon shark, Negaprion brevirostris, using tetracycline validated vertebral centra. Copeia 3:747-753

Castro JI (1993) The shark nursery area of bulls bay, South Carolina, with a review of the shark nurseries of the southeastern coast of the United States. Environ Biol Fish 38:3748. https://doi.org/10.1007/BF00842902

Centro Nacional de Áreas Protegidas (2013) Plan del Sistema Nacional de Áreas Protegidas 2014-2020. Ministerio de Ciencias Tecnología y Medio Ambiente, La Habana, Cuba

Cortés E (2002) Incorporating uncertainty into demographic modeling: application to shark populations and their conservation. Conserv Biol 16(4):1048-1062. https://doi. org/10.1046/j.1523-1739.2002.00423.x

Cortés E (2007) Chondrichthyan demographic modelling: an essay on its use, abuse and future. Marine Freshwater Research 58:4-6. https://doi.org/10.1071/MF06191

Davidson LNK (2012) Shark sanctuaries: substance or spin? Science 338:1538-1539. https://doi.org/10.1126 /science.338.6114.1538

Davidson LNK, Dulvy N (2017) Global marine protected areas to prevent extinctions. Nature Ecology \& Evolution 1. https://doi.org/10.1038/s41559-016-0040

DiBattista JD, Feldheim KA, Garant D, Gruber SH, Hendry AP (2011) Anthropogenic disturbance and evolutionary parameters: a lemon shark population experiencing habitat loss. Evol Appl 4:1-17. https://doi.org/10.1111/j.17524571.2010.00125.x

Dulvy NK (2013) Super-sized MPAs and the marginalization of species conservation. Aquat Conserv Mar Freshwat Ecosyst 23:357-362. https://doi.org/10.1002/aqc.2358

Duncan KM, Holland KN (2006) Habitat use, growth rates and dispersal patterns of juvenile scalloped hammerhead sharks Sphyrna lewini in a nursery habitat. Mar Ecol Prog Ser 312: 211-221. https://doi.org/10.3354/meps312211

Espinoza M, Cappo M, Heupel M, Tobin A, Simpfendorfer C (2014) Quantifying shark distribution patterns and specieshabitat associations: implications of Marine Park zoning. 
PLoS One 9(9):e106885. https://doi.org/10.1371/journal. pone. 0106885

Feldheim KA, Gruber SH, Ashley MV (2002) The breeding biology of lemon sharks at a tropical nursery lagoon. Proc R Soc Lond 269:1655-1661. https://doi.org/10.1098 /rspb.2002.2051

Freitas RHA, Rosa RS, Gruber SH, Wetherbee BM (2006) Early growth and juvenile population structure of lemon sharks, Negaprion brevirostris, in the atoll das Rocas biological reserve, off north-East Brazil. J Fish Biol 68:1319-1332. https://doi.org/10.1111/j.1095-8649.2006.00999.x

Gruber SH, Stout RG (1983) Biological materials for the study of age and growth in a tropical marine elasmobranch the lemon shark. NOAA Technical Report 8:193-205

Gruber SH, Nelson DR, Morrissey JF (1988) Patterns of activity and space utilization of lemon sharks, (Negaprion brevirostris), in a shallow Bahamian lagoon. Bulleting of Marine Science 43:61-76

Heithaus MR (2007) Nursery areas as essential shark habitats: a theoretical perspective. Am Fish Soc Symp 50:3-13

Henningsen AD, Gruber SH (1985) Assessment of two lemon shark, Negaprion brevirostris populations, by multiple mark procedures. Florida Scientist 48:32

Heupel MR, Hueter RE (2001) Use of an automated acoustic telemetry system to passively track juvenile blacktip shark movements. In: Sibert JR, Nielsen JL (eds) Electronic tagging and tracking in marine fisheries. Kluwer Academic Publishers, Netherlands, pp 217-236

Heupel MR, Hueter RE (2002) Importance of prey density in relation to the movement patterns of juvenile blacktip sharks (Carcharhinus limbatus) within a coastal nursery area. Mar Freshw Res 53:543-550. https://doi.org/10.1071/MF01132

Heupel MR, Carlson JK, Simpfendorfer CA (2007) Shark nursery areas: concepts, definition, characterization and assumptions. Mar Ecol Prog Ser 337:287-297. https://doi.org/10.3354 /meps337287

Hooker SK, Cañadas A, Hyrenbach KD, Corrigan C, Polovina JJ, Reeves RR (2011) Making protected area networks effective for marine top predators. Endanger Species Res 13(3):203218. https://doi.org/10.3354/esr00322

Hueter RE, Castillo-Géniz JL, Márquez-Farías JF, Tyminski JP (2007) The use of Laguna Yalahau, Quintana Roo, Mexico as a primary nursery for the blacktip shark (Carcharhinus limbatus). In: McCandless CT, Kohler NE, Pratt HL Jr (eds) Shark nursery grounds of the Gulf of Mexico and the east coast waters of the United States, American fisheries society. Symposium, vol 50, pp 345-364

Kelleher G (1999) Guidelines for marine protected areas. International Union for the Conservation of nature and natural resources. Gland, Switzerland and Cambridge, U.K.

Kessel ST, Hansell AC, Gruber SH, Guttridge TL, Hussey NE, Perkins RG (2016) Three decades of longlining in Bimini, Bahamas, reveals long-term trends in lemon shark Negaprion brevirostris (Carcharhinidae) catch per unit effort. J Fish Biol 88(6):2144-2156

MacKeracher T, Diedrich A, Simpfendorfer CA (2019) Sharks, rays and marine protected areas: a critical evaluation of current perspectives. Fish Fish 20(2):255-267. https://doi. org/10.1111/faf.12337

Manire CA, Gruber SH (1991) Effect of M-type dart tags on field growth of juvenile lemon sharks. T Am Fish Soc 120:776780

Martínez-Daranas B, Suárez AM (2018) An overview of Cuban seagrasses. Bull Mar Sci 94(2):269-282

McCandless CT, Kohler NE, Pratt HL (2007) Shark nursery grounds of the Gulf of Mexico and the east coast waters of the United States. Am Fish Soc Symp 50, Bethesda, MD

Morrissey JF, Gruber SH (1993a) Home range of juvenile lemon sharks, Negaprion brevirostris (Poey). Copeia 2:425-434

Morrissey JF, Gruber SH (1993b) Habitat selection by juvenile lemon sharks, Negaprion brevirostris. Environ Biol Fish 38: 311-319

Nagelkerken I, Blaber SJM, Bouillon S, Green P, Haywood M, Kirton LG, Meynecke JO, Pawlik J, Penrose HM, Sasekumar A, Somerfield PJ (2008) The habitat function of mangroves for terrestrial and marine fauna: a review. Aquat Bot 89:155 185

PAN-Tiburones (2015) Plan de Acción Nacional de Conservación y Manejo de Condrictios de la República de Cuba. Ministerio de la Industria Alimentaria. La Habana, Cuba. 48 p

Poey F (1868) Peces cubanos. Especies nuevas. Repertorio FísicoNatural de la Isla de Cuba, Vol. 2. La Habana: La Viuda de Barcina y Comp. 229-245

Roberts CM, Hawkins JP (2000) Reservas marinas totalmente protegidas: una guía. Campaña de mares en peligro del WWF. 1250 24th street, NW, Washington, DC 20037, EE.UU. y Environment Department, University of York, York, YO10 5DD, Reino Unido

Ruiz-Plasencia I (2017) Las áreas protegidas de Cuba. Centro Nacional de Áreas Protegidas (CNAP). La Habana, Cuba. $396 \mathrm{p}$

Salm RV, Clark JR, Siirila E (2000) Marine and coastal protected areas: a guide for planners and managers. IUCN, Gland, Switzerland

Simpfendorfer CA, Heupel MR (2004) Methods for studying habitat use in elasmobranchs. In: Carrier JC, Musick JA, Heithaus MR (eds) The biology of sharks and their relatives. CRC Press, Boca Raton, Florida, pp 553-572

Tavares R, Rodriguez JP, Morales M (2016) Nursery area and size structure of the lemon shark population, Negaprion brevirostris (Poey, 1868), in los Roques archipelago National Park, Venezuela. Univ Sci 21(1):33-52

White WT, Platell ME, Potter IC (2004) Comparisons between the diets of four abundant species of elasmobranchs in a subtropical embayment: implications for resource partitioning. Mar Biol 144:439-448. https://doi.org/10.1007/s00227-0031218-1

Publisher's note Springer Nature remains neutral with regard to jurisdictional claims in published maps and institutional affiliations. 